International Review of Social History 45 (2000), pp. 89-IIo

(C) 2000 Internationaal Instituut voor Sociale Geschiedenis

\title{
SURVEY
}

\section{The Policeman as Worker: A Comparative Survey \\ c. $1800-1940^{*}$}

\author{
Clive Emsley
}

In the exciting new social history of the 1960s the concept of class struggle tended to underpin much of the work on the working class in general, and on various labour groups in particular. Historians sought to find faces in crowds and to rescue others from "the enormous condescension of posterity". The police, however, when they appeared in this history, were usually as nameless and faceless as the crowds had been previously. They were also commonly portrayed as oppressors, and even in the more perceptive and ground-breaking attempts to explore the police themselves, they were seen through the refracted lens of their working-class critics as "blue locusts" and as a bourgeois instrument for controlling a new society. ${ }^{2}$ Parallel research conducted at roughly the same time by sociologists, social psychologists and others developed theoretical perspectives based on two assumptions: first, that certain kinds of authoritarian personality were attracted to police careers, and second, that policing roles had predictable effects on the behaviour and personality of policemen. Subsequent research has suggested these assumptions to be largely unfounded, yet in this respect also, historical explorations of policemen as workers remain few. ${ }^{3}$

* My thanks to Ian Cruse, Marcel van der Linden, Haia Shpayer-Makov, and Robert D. Storch for their helpful comments and suggestions on an earlier draft of this paper.

I. It was George Rudé's research which began to give "faces" to rioters and revolutionary crowds. See in particular, George Rude, The Crowd in the French Revolution (Oxford, 1959) and idem, Wilkes and Liberty: A Social Study of 1763 to 1774 (Oxford, 1962). In The Making of the English Working Class (London, 1963), p. I2, E.P. Thompson declared his intention "to rescue the poor stockinger, the Luddite cropper, the 'obsolete' handloom weaver, the 'utopian' artisan, and even the deluded follower of Joanna Southcott, from the enormous condescension of posterity".

2. Robert D. Storch, "The Plague of Blue Locusts': Police Reform and Popular Resistance in Northern England I840-1857”, International Review of Social History, 20 (1975), pp. 6I-90; idem, "The Policeman as Domestic Missionary: Urban Discipline and Popular Culture in Northern England, I850-1880", Journal of Social History, 9 (1976), pp. 48I-509.

3. George C. Browder, Hitler's Enforcers: The Gestapo and the SS Security Service in the Nazi Revolution (New York, 1996) stands out as a model for such work. 
For many years the history of the police was something undertaken largely by serving policemen, by former policemen, or by individuals who were closely connected with the police during their working lives. Henry Buisson, for example, who published a history of police in France in 1949 was an instructor at the École nationale de police and Commissaire principal de la Sûreté nationale. ${ }^{4}$ More recently Georges Carrot, who prepared a thesis on the maintenance of order in France and who, subsequently, published a series of texts on police history, also taught at the École nationale supérieure de police and was a commissaire divisionaire. T.A. Critchley, who wrote one of the more thoughtful histories of English policing before the current academic interest, was principal private secretary to the Home Secretary, R.A. Butler, from 1957 to 1962, secretary of the Royal Commission on Police from 1960 to 1962, and a senior member of the Police Department within the Home Office until $197 \mathrm{I} .{ }^{6}$ This traditional police history, as might be expected from its origins, is not necessarily uncritical but the overall aura is celebratory and it charts a steady, largely linear process to the present. A new trend began to emerge during the I970s particularly with studies of the English police; and it is interesting to note that several of the first of these were undertaken by North American scholars. ${ }^{7}$ Similar work began to appear for France and Germany during the 1980s, and is now being undertaken for Italy. In France much of the initial interest concerned mapping out the contours of police development in the Third Republic, and has now shifted to the painful period of World War II and its aftermath. ${ }^{8}$ For

4. Henry Buisson, La Police, son histoire (Vichy, 1949).

5. Georges Carrot, Le Maintien de l'ordre en France depuis la fin de l'Ancien Régime jusqu'à 1968, 2 vols (Toulouse, 1984); idem, Histoire de la police française (Paris, 1992).

6. T.A. Critchley, A History of Police in England and Wales (London, 1967; revised edition, 1978). 7. The seminal essays were those of Storch, "The Plague of Blue Locusts", and "The Police Man as Domestic Missionary". Also important, and especially significant because of their comparative nature, are Wilbur R. Miller, Cops and Bobbies: Police Authority in London and New York, 1830-1870 (Chicago, IL, 1977), and Stanley H. Palmer, Police and Protest in England and Ireland, 1780-1850 (Cambridge, I988) - a book which began life as a Harvard doctorate of 1973.

The police forces of the United States have largely been ignored for this essay. An excellent bibliographical survey is Eric H. Monkkonen, "History of Urban Police", in Michael Tonry and Norval Morris (eds), Modern Policing (Chicago, IL, I992), reprinted as "The Urban Police in the United States", in Clive Emsley and Louis A. Knafla (eds), Crime History and Histories of Crime: Studies in the Historiography of Crime and Criminal Justice in Modern History (Westport, CT, 1996).

8. Several important recent doctoral dissertations include Patricia Ann O’Brien, "Urban Growth and Public Order: The Development of a Modern Police in Paris, 1829-54" (Columbia University, NY, I973); Jean-Marc Berlière, "L'Institution policière sous la Troisième République" (Université de Bourgogne, 199I); Marie-France Vogel, "Les Polices des villes entre local et national L'Administration des polices urbaines sous la IIIe République” (Université de Grenoble II, I993); Simon Kitson, "The Marseille Police in their Context, from the Popular Front to Liberation" (University of Sussex, 1995); and Annie Lauck, "Les Représentations de la police Parisienne de la Restauration à la monarchie de juillet (1814-1832)" (Université de Paris I, Sorbonne, 1997). For the moment much of this work remains confined to the dissertations, but see Jean-Marc Berlière, Le Préfet 
Germany much of the focus has been on political policing since the beginnings of unification, on the control of the working class and the suppression of working-class organizations. ${ }^{9}$ However, the work of George C. Browder, Peter Leßmann and Elaine Glovka Spencer in particular has provided significant insights into the police themselves. ${ }^{10}$ For Italy, apart from Steven Hughes's interesting discussion of the fascination with the English "bobby" in the newly united state, the principal interest - again by Anglo-Saxon rather than native Italian historians - has been the late nineteenth-century liberal era and the period of the rise of fascism. ${ }^{\text {II }}$

This essay seeks, with a broad brush, to survey some of the recent work on the policeman of the nineteenth and early twentieth centuries. It focuses particularly on the policeman as a worker, restricted by a rigorous work discipline, but with his own work culture often as resistant to the demands of authority as that of other workers; and if much of the content discusses the English example, this is simply because so much of the recent work has been done on the English situation. Its time span of the nineteenth and first half of the twentieth centuries is the period when modern, bureaucratic policing was developed into the forms recognizable in the contemporary world. Of course, different concepts of "police" were understood before this, but bureaucratic police officials, maintaining regular patrols of their districts, emerged essentially out of the rational thinking of the Enlightenment; and while recent research on major cities during the eighteenth century reveals the emergence of such police well before the $1790 \mathrm{O},{ }^{12}$ police forces have commonly been linked with the development of state bureaucracies which came in the wake of the French Revolution and the Napoleonic imperium. There continue to be debates about the origins of modern police - particularly with reference to different countries or to individual

Lépine. Vers la naissance de la police moderne (Paris, 1993); idem, Le Monde des polices en France XIXe-XXe siècles (Brussels, I996).

9. See inter alia, Wolfram Siemann, Deutschlands Ruhe, Sicherheit un Ordnung. Die Anfänge der politischen Polizei I806-1866 (Tübingen, I985); Ralph Jessen, Polizei im Industrierevier: Modernisierung und Herrschaftspraxis im Westfälischen Ruhrgebiet, I848-I9I4 (Göttingen, 199I).

Io. Browder, Hitler's Enforcers; Peter Leßmann, Die preussische Schutzpolizei in der Weimarer Republik: Streifendienst und Strassenkampf (Düsseldorf, 1989); Elaine Glovka Spencer, Police and the Social Order in German Cities: The Düsseldorf District I848-1914 (DeKalb, IL, 1992).

II. Steven C. Hughes, 'Poliziotti, Carabinieri e 'Policemens': il 'bobby' inglese nella polizia italiana", Le Carte e la storia, 2 (1996), pp. 22-31; see also, Richard Oliver Collin, "The Italian Police and Internal Security from Giolitti to Mussolini", (D.Phil. Oxford, 1983); Richard Bach Jensen, "Police Reform and Social Reform: Italy from the Crisis of the I89os to the Giolittian Era", Criminal Justice History, Io (1989) pp. I79-200; idem, Liberty and Order: The Theory and Practice of Italian Public Security Policy, I848 to the Crisis of the I89os (New York, I991); Jonathan Dunnage, The Italian Police and the Rise of Fascism: A Case Study of the Province of Bologna, I897-1925 (Westport, CT, 1997).

I2. Alan Williams, The Police of Paris $1718-1789$ (Baton Rouge, LA, 1979); Elaine A. Reynolds, Before the Bobbies: The Night Watch and Police Reform in Metropolitan London, I720-I830 (London and Basingstoke, 1998). 
forces - but it probably remains fair to argue that most police organizations established during the late eighteenth and nineteenth centuries were designed essentially to ensure a greater certainty of punishment for the criminal offender, and to establish the rational order aspired to by both the state jurist and what, for convenience sake, might be distinguished as emerging "bourgeois" society. A final point of introduction: the word "policeman" is used below conscious of its gender specificity; women police officers did not exist before World War I, and they were largely restricted to the "domestic sphere", principally the supervision of women and children, until after World War II. ${ }^{13}$

\section{RECRUITS TO THE POLICE}

The police officer is the only official within the modern state authorized to use violence in day-to-day dealings with ordinary citizens. Indeed, David $\mathrm{H}$. Bayley has argued that this use of force is a major element in the definition of police and distinguishes the police from other public agencies. ${ }^{14}$ The use of force to impose new bourgeois values, and the use of force pure and simple, were among the first topics approached by the new historians of police. ${ }^{\text {Is }}$ But the role of force in police tasks accepted, there are many varieties of police, and many different tasks within the job. Administratively, during the nineteenth and twentieth centuries, there were three broad types in the European world: the state civilian police, answerable to central government, usually found in capital cities but, increasingly also elsewhere; the municipal civilian police, answerable to, and largely funded by local government; and the state military police, the gendarmeries, commonly responsible to both the Ministry of the Interior and the Ministry of War, usually deployed in the countryside, but also useful as the first line of defence in times of internal crisis. ${ }^{16}$ Within these three types there was a wide range of ability and sophistication. The municipal police had the broadest range, encompassing at one extreme the disciplined, uniformed men of a large city police institution not greatly different from a statecivilian force, while at the other extreme came the rural guard, possibly with

I3. See, for example, Ursula Nienhaus, "Einsatz für die 'Sittlichkeit': Die Anfänge der weiblichen Polizei im Wilhelminischen Kaiserreich und in der Weimar Republik", in Alf Lüdtke (ed.), "Sicherheit" und "Woblfahrt". Polizei, Gesellschaft und Herrschaft im I9. und 20. Jahrhundert (Frankfurt am Main, 1992); Philippa Levine, "Walking the Streets in a Way No Decent Woman Should': Women Police in World War One", Journal of Modern History, 66 (1994), pp. 34-78.

14. David H. Bayley, Patterns of Policing: A Comparative International Analysis (New Brunswick, NJ, 1985), especially chs I and 2.

I5. Storch, "The Policeman as Domestic Missionary"; Clive Emsley, "The Thump of Wood on a Swede Turnip': Police Violence in Nineteenth-Century England", Criminal Justice History, 6 (1985), pp. I25-I49.

I6. Clive Emsley, "A Typology of Nineteenth-Century Police," Crime, histoire \& sociétés/Crime, History \& Societies, 3 (1999), pp. 29-44. 
little in the way of a uniform and probably heavily dependent on local landowners and other worthies for his post. But whatever the differences between the police institutions, the skills of policing for most of the nineteenth and twentieth century were minimal and largely unsophisticated. As today, most policemen were assigned to patrol work ${ }^{17}$ of which more below, and very little of their time was concerned with crime. There were detective squads who enjoyed the praise of journalists and who, through those journalists, boasted specialized skills in detecting and tracking down offenders. ${ }^{18}$ In the light of much recent criminological research, however, these boasts need to be viewed with caution. ${ }^{\text {I9 }}$

Nineteenth- and early twentieth-century policemen came, overwhelmingly from the unskilled and semiskilled working classes. ${ }^{20}$ Around threequarters of posts in the police of Paris during the nineteenth century were specifically reserved for former soldiers with at least five years service. ${ }^{21}$ The intention was that the police of Prussian cities would be similarly recruited, though good men were not always available, especially in the Rhineland from the 1870s, where the pay of industrial workers outstripped that of ordinary policemen. ${ }^{22}$ The English police forces had a much larger proportion of men with military experience than the traditional picture of the

17. David H. Bayley, Police for the Future (New York, 1994), p. I6, notes that from a study of twenty-eight modern police forces sixty-five per cent are assigned to patrol work in the USA, sixty-four per cent in Canada, fifty-six per cent in Britain, fifty-four per cent in Australia, and forty per cent in Japan. Moreover, in general only fifteen to twenty per cent of calls to the police concern crime (p. i7)

I8. Examples of journalistic praise can be found in W.H. Wills, "The Modern Science of ThiefTaking", Household Words, I (I850), pp. 368-372; Charles Dickens, "A Detective Police Party", Household Words, I (I850), pp. 409-4I4 and 457-460; Maxime du Camp, Paris: ses organes, ses fonctions et sa vie dans la seconde moitié du XIXe siècle, 6 vols (Paris, I883-I898), 3, esp. p. 85.

I9. See, inter alia, Peter W. Greenwood, Jan M. Chaiken, Joan Greenwood, et al., The Criminal Investigation Process (Lexington, MA, 1977), and David Steer, Uncovering Crime (London, 1980). The research emphasizes that most offenders are caught either at the scene of the offence, or as a result of positive identification by witnesses or victims, rather than by clever detective work.

20. Much more work needs to be done on the origins of the different kinds of policemen; this paragraph is based largely on, for England, Clive Emsley and Mark Clapson, "Recruiting the English Policeman C.I840-I940", Policing and Society, 3 (I994), pp. 269-286, and see also W.J. Lowe, "The Lancashire Constabulary, I845-1870: The Social and Occupational Function of a Victorian Police Force", Criminal Justice History, 4 (1983), pp. 4I-62; Haia Shpayer-Makov, "The Making of a Police Labour Force", Journal of Social History, 24 (I990), pp. I09-134; idem, "A Portrait of a Novice Constable in the London Metropolitan Police around 1900", Criminal Justice History, II (I99I), pp. I33-I60; idem, "The Appeal of Country Workers: The Case of the Metropolitan Police”, Historical Research, 64 (I99I), pp. I86-203; for France, Capt. Louis Saurel, "La Gendarmerie dans le société de la Deuxième République et du Second Empire”, 3 vols, (Doctorat d'état, Université de Paris, 1964), 2, pp. 58-77, and Terry W. Strieter, "The Faceless Police of the Second Empire: A Social Profile of the Gendarmes of Mid-Nineteenth-Century France”, French History, 8 (1994), pp. I67-I95; for Ireland, Brian J. Griffin, "The Irish Police I836-I9I4”, (Ph.D., Loyola University, Chicago, IL, I99I).

2I. Berlière, Le Préfet Lépine, pp. 130-138.

22. Spencer, Police and the Social Order, pp. 38, 56-58 and 9I-97. 
avuncular, unarmed "bobby" would suggest, though the recruitment of former soldiers varied from force to force and decisions on whether or not to recruit ex-soldiers was taken at the local level. Gendarmes, and their equivalents elsewhere in Europe - Carabinieri, Guardia Civil, Landjägers generally continued to be considered as soldiers throughout their "police" service. The case has been argued that nineteenth- and early twentiethcentury policemen were recruited from outside the communities in which they served; the control and surveillance functions of policing were supposed to be easier for men who had no local ties. In England, however, the decision of whether or not to recruit local men was again one which was usually taken locally; some chief constables strictly limited the number of local recruits, but elsewhere, and especially in the rural constabularies, local men were common. In France there was difficulty in finding local men for the companies of la Gendarmerie nationale in some départements; but elsewhere there was often a tradition of local men, and it was recognized that such men were valuable in as much as they knew the local dialects and languages. Even where men were not allowed to serve in their county or province of birth it was possible for close links to develop between policemen and the local community. The Royal Irish Constabulary, for example, was a gendarmerie-type institution which would not allow a man to serve in either the district of his birth nor that of his wife. The Constabulary carried out unpopular tasks during the famine of I845-1846 and helped suppress risings in 1848 and the I86os, but the men themselves only appear to have become seriously unpopular as a body with the rural communities in which they served, during the Land War in the early I88os.

When the police forces were first established many men appear to have joined to tide themselves over a period of unemployment. Writing in 1893 , Timothy Cavanagh considered that "nine-tenths of all who have ever joined [the London Metropolitan Police] [...] from its formation in 1829 to the present have done so through 'stress of weather'". Cavanagh himself had joined in 1855 when out of work. ${ }^{23}$ Former soldiers may have been attracted into the different police organizations because during their military service they had become accustomed to, and comfortable with, working in a disciplined, hierarchical institution. Some, who joined the gendarmeries or the state-civilian forces, may have absorbed and accepted the military ideology of service to the state and/or the monarch; in this respect it is significant to note the importance which gendarmes appear to have given to the oath which they swore on enlistment. ${ }^{24}$ But such sentiments probably had little impact on the men who served in municipal forces, especially the smaller

23. Timothy Cavanagh, Scotland Yard Past and Present: Experiences of Thirty-Seven Years (London, I893), p. 2.

24. Clive Emsley, Gendarmes and the State in Nineteenth-Century Europe (Oxford, 1999), esp. pp. $257-258$. 


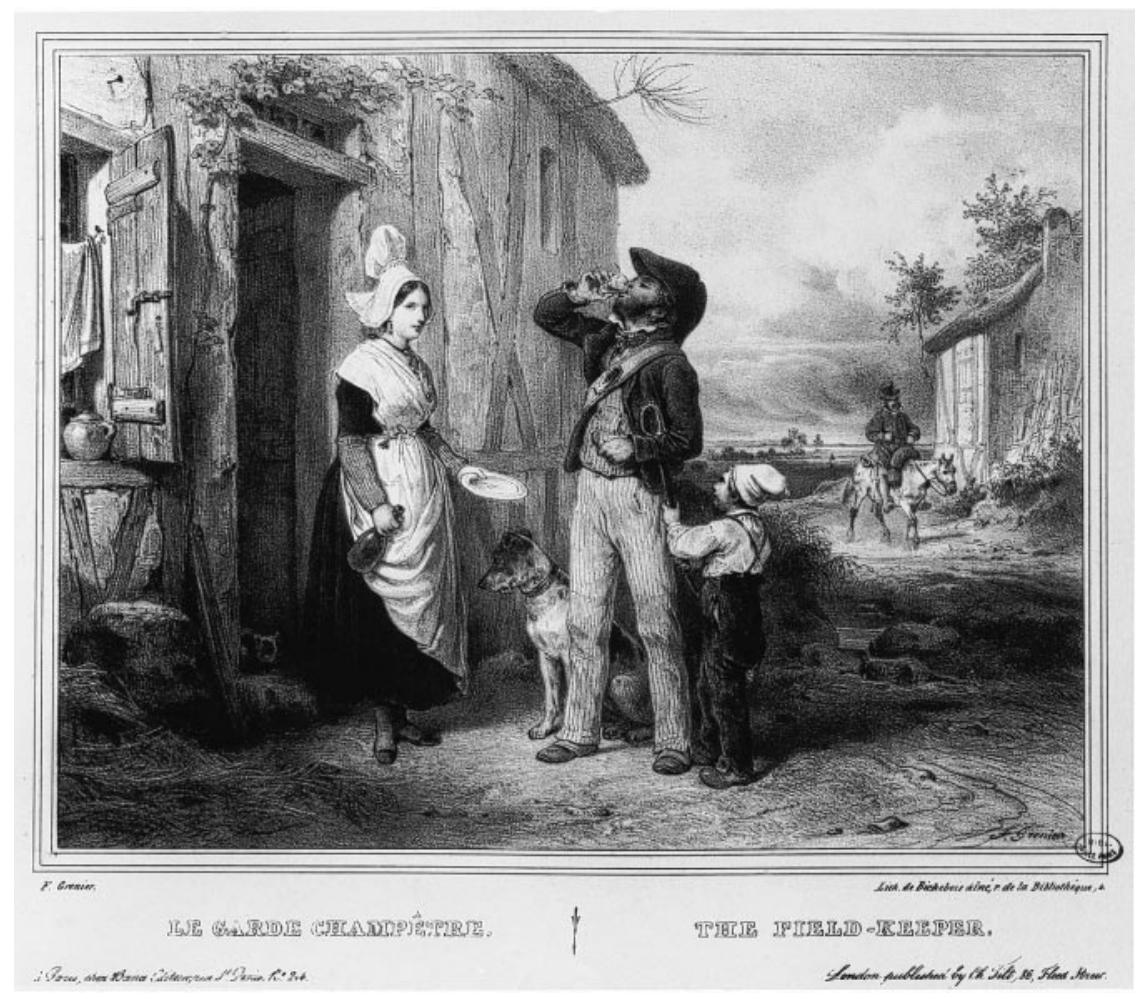

Figure I. The garde-champêtre. The garde-champêtre was the local policeman in rural France. In I79I the National Assembly authorized rural communes to appoint such guards to protect crops and property. There were periodic proposals to put them on a more formal and institutionalized footing, but throughout the nineteenth and early twentieth centuries they remained local appointees, commonly disparaged by the gendarmes who had a degree of supervision over them. In contrast to this early nineteenth-century, romantic representation, the guards have generally received a bad press as inefficient drunkards, creatures of the local mayors, and too closely linked with the communities in which they served. However, the men themselves, their tasks and how they performed them await serious historical study.

Musée Carnavalet; copyright Photothèque des musées de la ville de Paris

rural ones. ${ }^{25} \mathrm{~A}$ few peasant soldiers on continental Europe may have lost their patrimony during their army service, and more importantly may have lost their feel for, and interest in, the hard life working the land. Police service in such an instance provided an alternative; and for a few there was probably also the attraction of lording it over the people from among whom

25. Rural guards have, to date, been particularly poorly researched; for some new work on the subject see Vicent R. Mir Montalt, Desposeer y custodiar. Transformación agraria y guardería rural en la provincia de Valencia 1844-I874 (Valencia, 1997), and Fabien Gaveau, "L'Ordre aux champs. Pour une histoire des gardes champêtres 1789-I880" (Mémoire de DEA d'histoire, Université de Bourgogne, Dijon, I997). 
they had originated in a uniform and with authority. For some men the police became the family métier; brothers followed brothers, and sons followed fathers into police ranks.

\section{PAY AND CONDITIONS}

Police institutions offered regular pay even if it was not necessarily on a level with that of many of the more respectable working-class trades. ${ }^{26}$ In nineteenth-century England the belief that wage rates were not permitting police officers to maintain their wives and families at the level of respectability that seemed to be expected of men in the job provoked industrial action. In June I853 just over half of the Manchester police resigned in a body protesting the difficulty of meeting rent and fuel bills out of their pay. There was, they insisted, less than two shillings a week left available for the

[...] food and raiment becoming the family of a police constable, who should appear as respectable members of society. Where are the domestic utensils, household clothing, and lastly - though not least - the children's schooling to come from? It is very much to be doubted whether our authorities would be very anxious to appoint our sons as police-constables, who had been educated and reared on so small a pittance. ${ }^{27}$

Annoyance was also expressed over the impact on the police family of work restrictions imposed on policemen's wives. "The mechanic gets from 3os. to 36s. for 60 hours a week", protested one constable in 1867 ,

[...] and his wife may keep a cow if he lives in a country place and a shop if he lives in town, and nothing said about character, height, or handwriting; these are qualities not required of him. The police constable is paid 2os. or 2Is. if he is in the Ist. class for at least 98 hours' duty and is required in addition to bring satisfactory testimonials, write a good hand, be of a certain height, and able to withstand all temptations to which he is continually exposed; his wife is not allowed to keep a cow or a shop; he must be ready at any time to remove to any other part the Chief Constable may think fit to order him, and he is expected to keep himself independent of the world, and keep a wife and 5 or 6 children in a respectable appearance, and provisions at the rate they are. $^{28}$

Similar dissatisfaction led to industrial action within the London Metropoli$\tan$ Police in the early I870s and again in the I88os. At the turn of the century there was an attempt to develop a trades union for police and prison officers in England, and the pressures of the First World War coalesced with the continuing dissatisfaction to prompt a strike within the Metropoli-

26. David Taylor, "The Standard of Living of Career Policemen in Victorian England: The Evidence of a Provincial Borough Force", Criminal Justice History, I2 (1991), pp. I07-I3I.

27. Manchester Guardian, II June I853.

28. Police Service Advertiser, 27 April 1867. 
tan Police in 1918. A second, much wider strike was called in the following year; the intention was to preserve the union, but it was a disastrous failure. $^{29}$ In Ireland in the summer of I 882 there was trouble among both the Royal Irish Constabulary and the Dublin Metropolitan Police. The men in both forces felt that they had been put under excessive pressure by the events and policing requirements of the Land War. In addition, they were concerned about lagging pay and benefits for career policemen, about a complex and inequitable pension system, and, once the unrest began, about intemperate language by senior officers which served primarily to strengthen resolve and increase the dissatisfaction. ${ }^{30}$ In France too, at the end of the nineteenth and beginning of the twentieth centuries, there was agitation among the different sections of the police, though not among the gendarmerie which, while it tended to be neglected in comparison with the statecivilian police, maintained its strict, military nature. In January I884, for example, there was serious unrest among the gardiens de paix in Paris concerned about the certainty of their pensions. ${ }^{3 \mathrm{I}}$ At the beginning of the new century the police, like other state functionaries, began to establish amicales (friendly or benevolent societies) since they were not allowed to create syndicats (formal unions); and in 1907 there was a week-long strike among the police in Lyon - a state-civilian, as opposed to a municipal-civilian institution. The police amicales came together in a national federation and, by the First World War this had, to all intents and purposes, developed into a trades union..$^{32}$ Union organization emerged in the police institutions of other countries during roughly the same period and in 1927 the Internationale Föderation der Polizeibeamten was established in Berlin, drawing its membership from unions in Austria, Belgium, France, Germany, the Netherlands and Scandinavia. ${ }^{33}$ Policemen may have been deployed often against the interests of labour, but as workers themselves they were prepared to organize and issue demands on their own behalf. While some police activists sought to distance themselves from revolutionaries and syndicalists, there were a few who urged policemen to unite with other workers in a common struggle or who were prepared to seek the support of other labour organizations or even of political groups on the left. ${ }^{34}$

29. Emsley, English Police, pp. 95-103 and $132-135$.

30. Fergus A. D’Arcy, "The Dublin Police Strike of I882", Saothar, 23 (1998), pp. 33-44; W.J. Lowe, "The Constabulary Agitation of I882", Irish Historical Studies, 3I (1998), pp. 37-59.

31. Archives de la Préfecture de Police, Paris, DB 34 and DB 515.

32. Jean-Marc Berlière, "Quand un métayer veut être bien gardé, il nourrit ses chiens. La Difficile naissance du syndicalisme policier. Problèmes et ambiguités (1900-1914)", Le Mouvement social, 164 (1993), pp. 25-5I; Michel Bergès, Le syndicalisme policier en France (I880-1940) (Paris, 1995).

33. My thanks to Marie-France Vogel for information on this organization.

34. During I890, for example, police activists in London had links with both trades unions and the Social Democratic Federation; Emsley, English Police, pp. 98-99. In March 1914 Louis Joubert wrote a series of articles in Rappel noting that low police salaries came from taxes paid by hardpressed workers, and urging the two groups to unite for the preservation of the Third Republic. 
While policemen might feel oppressed by their employers, there were some perquisites which went with the job and which, while a monetary value is not always easy to assign to them, could help to eke out a family budget or enable a man to take time off to solve a family problem. The issue of a uniform and footwear was a clear saving to the pay of a single or a married man. ${ }^{35}$ Medical provision was available, though it was also the case that policemen were much more likely to be assaulted than men in most trades, while the effects of patrolling in any and all weathers was noted as having a serious effect on the health of even the toughest individuals. "The periodical reappearance of influenza and the general aggregate of throat and chest troubles comprise the great majority of [sickness] cases", commented one of His Majesty's Inspectors of Constabulary in his report for 1932. "It is remarkable to find this general effect of police work upon strong constitutions - particularly having regard to the well-equipped conditions of the police in the matter of clothing. There can be no doubt that there is ample proof of the exposure factor in police duty [...]. ${ }^{36}$ In some instances the medical provision could even be extended to a man's family. The gendarmeries in particular appear to have been prepared to give men compassionate leave. In France gendarmes were able to take advantage of the military schools for the free, or almost free education of their sons. ${ }^{37}$

The biggest formal perquisite of the job for the nineteenth-century policeman was the pension on retirement. The pension could also be accompanied by the offer of other work on behalf of the central or the local state. In Germany some men appear to have seen the police as a stepping stone between the army and another appointment in the civil service; the final civil service post also carried a pension, and the life promised to be much quieter and less exacting than that of the Schutzmann..$^{38}$ A retired policeman, particularly one with a record of good conduct, was seen as ideal for certain jobs possibly, but not necessarily, connected with the justice system. In nineteenth-century France a few former gendarmes were seen as potential candidates for the post of commissaire de police in rural cantons. ${ }^{39}$ In England, during the interwar years, the question was raised in Parliament as to whether it was justifiable for retired policemen, drawing "handsome pensions", to be given good jobs in local government and elsewhere when so

35. Though not every police institution issued uniforms. In some German cities in the midnineteenth century, policemen had to purchase their own uniforms; Spencer, Police and the Social Order, p. 37.

36. Report of His Majesty's Inspectors of Constabulary for the Year ended 29th September 1932, p. 7. 37. Emsley, English Police, p. 216; Saurel, "La Gendarmerie dans la société", 2, pp. 523-527; Strieter, "The Faceless Police of the Second Empire", p. I87.

38. Albrecht Funk, Polizei und Rechsstaat. Die Entwicklung des staatlichen Gewaltmonopols in Preussen I848-I9I4 (Frankfurt, 1986) p. 290.

39. Strieter, "The Faceless Police of the Second Empire", p. I83. 
many were unemployed..$^{40}$ There is, however, the major problem of assessing precisely how far the prospect of a pension loomed in the minds of workingclass men in the nineteenth and early twentieth centuries when they opted to join a police force or gendarmerie. Pensions were not something which were common in working-class occupations; it seems possible that the value of the pension became more apparent to a man as he neared the end of his police service, encouraging him to stick out his duties to the end rather than opting for the uncertainties of another area of the labour market. Significantly, the trouble in the Irish police in 1882 occurred as men who had enlisted under the pension arrangements established in I866 and I867 began to recognize that these were significantly inferior to those of their comrades who had joined under earlier, more generous schemes. ${ }^{4 \mathrm{I}}$ In England the pension could be subject to the vagaries of local municipal circumstances until the Police Act of 1890 . This dictated a degree of uniformity in police pensions and as a result a man could, ordinarily, expect an annual pension of three-fifths of his annual pay after twenty-five years of service, whatever his age; he was also entitled to a pension after fifteen years of service if forced to retire on medical grounds. In nineteenth-century Rhineland cities, so as to save on pension costs, the municipalities endeavoured to keep men serving in the police for as long as possible, sometimes moving them to lighter duties. As a consequence, in the last quarter of the century disability became the most common reason for a man to receive his pension, and more men died in the job than retired on their pension. ${ }^{42}$

As with the pension, so the possibilities of social advancement through police service may not have loomed large in the mind of a young man when he joined, yet, for a few, such possibilities existed. Throughout the nineteenth century it was possible for a man to join an urban English police force at the lowest rank, and to rise to the rank of head constable in command of such a force at the end of his career. The inclination of many municipal police authorities towards the end of the nineteenth century to look to gentlemen with limited police experience to command even the smaller forces was one of the elements which fed into the unrest and the moves towards establishing a trades union. ${ }^{43}$ The structure of many of the continental forces militated against even the limited promotion opportunities within the English police. A man who entered the Paris police as a sergent de ville, or later gardien de paix, was unlikely to be able to pass to the rank of commissaire, and it appears to have been much the same in the other big towns. Ranks like those of commissaire and, in Italy, questore were entered

40. Hansard, 5 March 1936, cols I637-I638.

4I. D’Arcy, "Dublin Police Strike", p. 42; Lowe, "The Constabulary Agitation", pp. 40 and 55-56. 42. Spencer, Police and the Social Order, pp. 38 and 6o.

43. David S. Wall, The Chief Constables of England and Wales: The Socio-Legal History of a Criminal-Justice Elite (Aldershot, 1998) pp. I32-139 discusses debates in the "trade" journal Police Review shortly before World War I on the appointment of chief constables and promotions. 
directly and, as the nineteenth century wore on, increasingly by men with some legal training and the intention of moving up the career ladder as a state functionary. There were, however, opportunities for men to rise from the ranks to become officers in some of the gendarmeries, though the evidence is strongest, or at least best researched for the French institution. ${ }^{44}$ Men entering the Sicherheitsdienst (SD) during the early I930s improved their social standing. However, as they moved into a new social group these policemen were often treated as parvenus and given scant respect by their new peers. Upward social mobility does not necessarily appear immediately positive to individuals who experience it in this way. ${ }^{45}$

\section{THE RIGOURS OF THE JOB}

Pay, pensions, perks, and social mobility all could have a bearing on a policeman's attitude to his job, but the key element in whether a man stuck with the trade to his pension, was how he coped with the day-to-day tasks and rigours. For most policemen during the nineteenth and early twentieth centuries the job of policing meant, quite simply, patrolling. For constables of London's Metropolitan Police, who became a model of state-civilian police for liberals, at least in Europe, as well as for the big cities of the United States, patrolling meant maintaining a steady pace through a fixed series of streets for a six- or eight-hour shift. As much as two-thirds of patrolling was done at night when criminal offenders were thought to be at their most active, and on such patrols the constable was expected to check that doors and windows were securely fastened..$^{46}$ If a property was not secure, the owner was to be alerted to the fact. Any constable who missed an open, or an unlocked door or window where, subsequently, there was a break-in, could be severely punished. In addition the patrols were expected to enforce order maintenance in the broadest sense from moving on any noisy groups which had gathered in the street, to ordering the removal of obstructions to the roadway or pavement. The growth of traffic within urban areas, especially following the introduction of motor vehicles, meant that more and more men were drawn away from patrolling to supervise traffic, but as late as the eve of the Second World War the foot patrol remained the basic task of urban policing.

44. Emsley, Gendarmes and the State, pp. 90, I43, I86-I87 and 258. My impression is that social mobility in the Italian Carabinieri, and in some other corps, became more limited as the nineteenth century wore on, but the question needs to be researched in detail.

45. Browder, Hitler's Enforcers, pp. 137-138.

46. In the early twentieth century the Chief Constable of Bedfordshire included, in his quarterly reports, the number of doors and windows that his men had found unfastened on their night patrols. From early I9I4 he also began listing the number of unfastened hen-coops, and from early 1920 the number of "insecure Huts, with tools in them, on Allotments"!; Bedfordshire County Record Office, SJP I2 and SJP I6. 

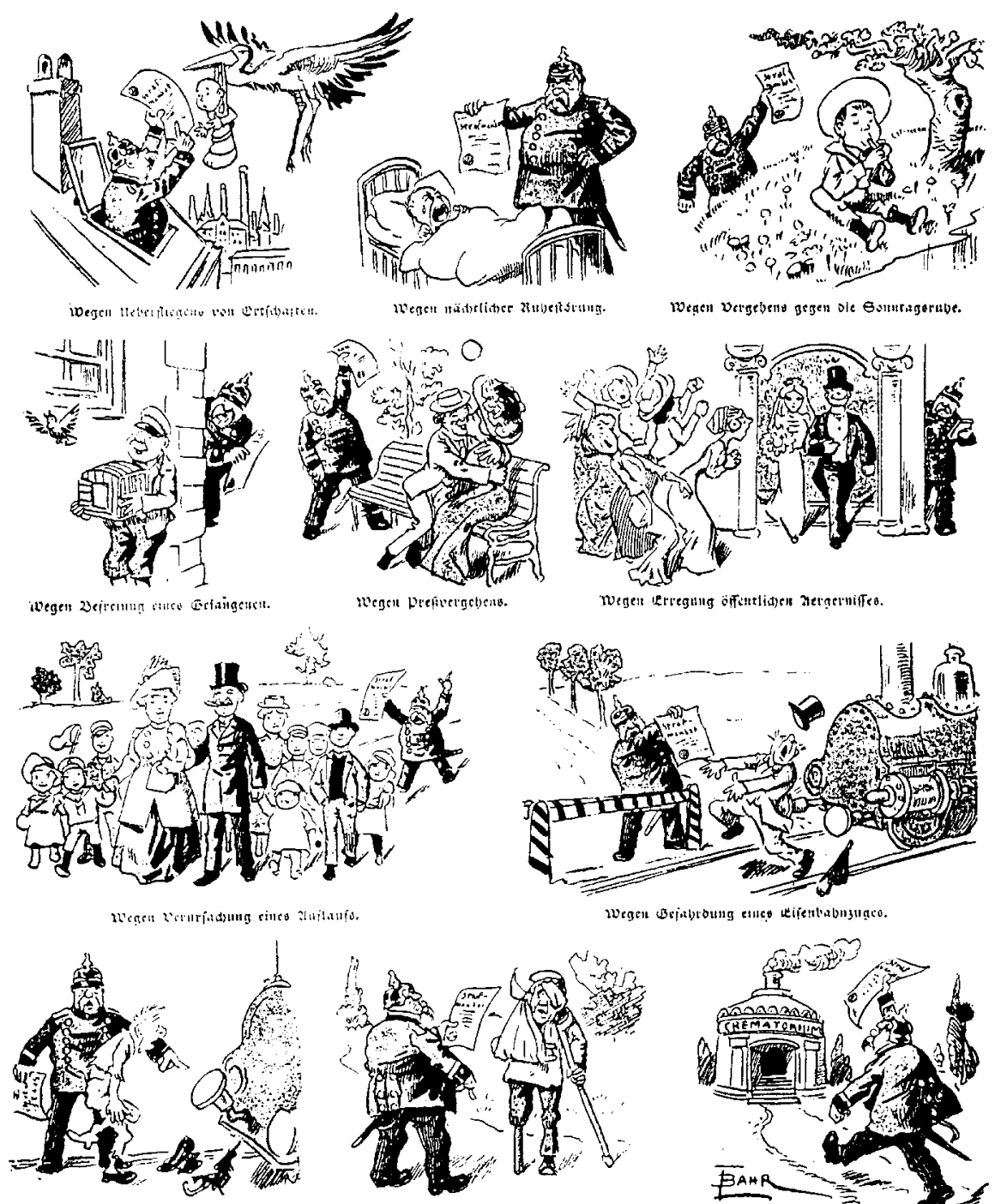

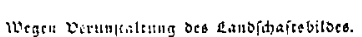

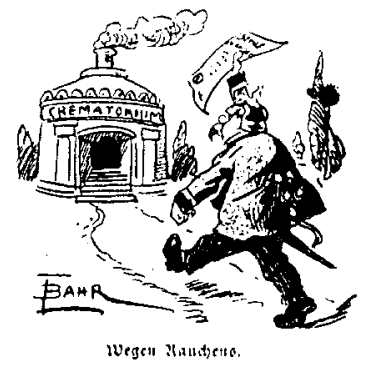

Figure 2. "Der Mensch und das Strafmandat". A caricature from the Lustige Blätter, I9II, which ridicules the way in which police ordinances were required for all forms of behaviour in Imperial Germany.

Reproduced from Wolf Dieter Lüddecke, Wie sich die Zeiten andern! Polizei-Geschichte im Spiegel von Karikatur und Satire (Verlag Deutsche Polizeiliteratur GMBH: Duisseldorf, 1988). Used with permission. 
As a rule, policemen had a much greater area to patrol than their urban counterparts. The set daily beat, to be covered at a steady pace, was largely irrelevant in the countryside. Rural policemen - English constables, French gendarmes, forest guards, or whoever - still patrolled; they had their routes carefully delineated by their superior, and were commonly required to liaise with colleagues or superiors at set times and in set places. For the constable in rural England such meetings were known as "conference points"; for the French gendarme they were correspondances.

English police constables, both rural and urban, generally patrolled on their own. Gendarmes in rural Europe commonly patrolled in pairs - the main exception seems to have been in the various German lands where gendarmes were stationed on their own rather than in barracks in squads of six to a dozen men. This practice of the two-man patrol was established during the eighteenth century among the Maréchaussée, the French precursor to the Gendarmerie nationale. The assumption appears to have been that two men made a better impression as a patrol, and that two men were better than one when it came to confronting suspects. In Spain this practice earned members of the Guardia Civil the nickname 'la Pareja'; by the I930s at least the story was current that the guardias patrolled in pairs because of their unpopularity, though whether this was indeed the case, like the history of the corps in general, needs further research. ${ }^{47}$

Training for patrol work was rudimentary. For most of the period and in most police institutions recruits appear to have been trained on the job by experienced men. Training schools began to be introduced at the close of the nineteenth century, particularly to provide a rudimentary knowledge of the law. The development of police departments with particular skills, such as detectives and motorized units, also required specialized instruction. But policing never required a formal apprenticeship; it was a respectable working-class trade by definition, but patrolling was unskilled work.

Whether patrolling singly or in pairs, policemen were working-class men required to act on their own initiative with no superior to direct their work while they were on the job. The problem for the superior officers was how to ensure that the ordinary patrolling policeman did his job. With relatively short beats in towns and cities it was possible for sergeants to conduct supervisory patrols. The supervision of rural policemen in this way was rather more difficult; the solution was for them to maintain careful journals detailing their patrols and describing any incidents with which they had to deal. Once again, following a practice established for the Maréchaussée

47. Gerald Brenan, The Spanish Labyrinth: An Account of the Social and Political Background of the Civil War, 2nd edn (Cambridge, 1950), p. 157. For the history of the Guardia Civil see Enrique Martinez Ruiz, Creación de la Guardia Civil (Madrid, 1976) and Diego López Garrido, La Guardia Civil y los origines del estado centralista (Barcelona, 1982). Neither volume, however, can be considered a social history and they have little to say about the guardias themselves - their origins, their work practices, what men did when they retired. 
during the eighteenth century, gendarmes carried a journal which they had to have signed by the mayor of a town or village, or by his deputy or another local worthy, whenever a patrol took them through that jurisdiction. ${ }^{8}$ The journals were regularly presented for inspection by senior officers. If the journal was satisfactory the superior signed it as such. Men were punished if ever it became clear that entries were incorrect or that a journal had been deliberately falsified.

Inspection rapidly became something to which the policeman had to submit himself as a part of the job. Some police institutions also developed systems of annual inspection by senior officers who were independent of the local force. The system of inspection for the French gendarmerie dated back to the eighteenth century and the Maréchaussée. Each year the departmental companies would be inspected by general officers from Paris. Brief reports were written on each man, with a general assessment of the whole company and its disposition. Lieutenant La Roche's memoir implies that there was considerable agitation in his company when the name of their inspector general was announced since he was known to be "très sévère". La Roche believed that his company was rigorously inspected, and he, personally, had the satisfaction of not being the subject of any comment - "chose bien rare avec $M M$ les inspecteurs généraux!". ${ }^{49}$ However, there were criticisms of the inspections for dragging men away from their daily duties and consequently leaving their districts unprotected; and a historical assessment of the inspections concluded that they probably achieved very little. ${ }^{50}$ While the English system of local government prided itself on its independence and decentralization, as part of the 1856 County and Borough Police Act a group of officers were established - Her Majesty's Inspectors of Constabulary - whose task it was to carry out annual inspections of the police forces and report on their efficiency to Parliament. Only "efficient" forces were to receive the initial annual treasury grant of one-quarter the cost of pay and uniforms; the grant rose to one-half of these costs in 1874, and, in the aftermath of World War I, to one-half the total cost of the force. As in France, these inspections excited trepidation, though given the time available and the small number of inspectors - there were only three inspectors for around 200 forces for more than the first fifty years of the system - the

48. Unfortunately, though perhaps understandably, few of these journals appear to have survived, though some are scattered in archives and museums in France, Germany and Italy. See Clive Emsley, "Les Gendarmes et les paysans. Vers une histoire institutionelle et social comparée", in Frédéric Chauvard et Jacques-Guy Petit (eds), L'Histoire contemporaine et les usages des archives judiciaires (I800-1939) (Paris, 1998), pp. 312-313.

49. Vicomte Aurélien de Courson (ed.), Souvenirs d'un officier de gendarmerie sous la Restauration, 3rd edn (Paris, I914), pp. I48-I49. See also Ignace-Emile Forestier, Gendarmes à la belle époque (Paris, 1983), pp. 85-87. Some of the reports of the inspectors-general survive for the Napoleonic and Restoration periods; see Archives de la Guerre (Vincennes), Xf 92, 97, 98, 256, and 257. 50. Saurel, "La Gendarmerie dans la société, I", pp. I87-I98. 
inspections appear often to have been cursory, while the questions asked of the men were not always either particularly taxing or particularly relevant to their policing tasks. ${ }^{\text {SI }}$

It probably did not take individual policemen long to find out precisely what their superiors were looking for in their journals, and to ensure that the journals were filled in accordingly. A participant observation study of contemporary English police officers noted how they tend to distinguish between two kinds of trouble - "on the job" and "in the job".$^{2}$ The former concern the routine problems which arise on the street from handling minor disorder to making an arrest; it is regarded as something which goes with the job. "In the job" trouble, however, is rather different. It concerns relationships with senior officers, with legal authorities, or with members of the public. In-the-job trouble is not something which is part of the job; it comes about as a result of a possible error of judgement, its results can be long and drawn out, and it is something best avoided. The avoidance of such trouble can be established by the careful management of information, and at times this might mean non-disclosure, partial disclosure, or a complete revision of the event. Moreover, this behaviour does not necessarily involve single policemen; sometimes this management of information can be organized by a group. Senior police officials employed such tactics to demonstrate to their political superiors how busy their men had been. Thus, during the nineteenth century, officers of the French gendarmerie listed the number of patrols their men made in a month, the number of fairs and village fêtes they supervized, the number of procès-verbaux sworn before them. ${ }^{33}$ Some English chief constables in the interwar years even went so far as to list in their annual reports, together with the number of arrests made and traffic accidents dealt with, how many phone calls were answered by the different divisions of their force. ${ }^{54}$ This kind of exercise can be dismissed as an excess typical of certain forms of bureaucracy. Understandably,

51. One man, recalling his service with the Cambridgeshire Constabulary during the I920s, remembered Sir Edward Dunning, Inspector of Constabulary, asking men: "How far is your village from headquarters?" or "How many square yards in an acre?"; Clive Emsley (ed.), "The Recollections of a Provincial Policeman: Arthur Ernest Almond", Journal of the Police History Society, 3 (1988), p. 58. The reports of the Inspectors of Constabulary published annually among the British parliamentary papers give very little information about how the inspections were conducted.

52. M.R. Chatterton, "The Supervision of Patrol Work under the Fixed Points System", in Simon Holdaway (ed.), The British Police (London, 1979); idem, "Police Work and Assault Charges", in Maurice Punch (ed.), Control in the Police Organization (Cambridge, MA, I983). Also interesting on this point is J. Goldstein, "Police Discretion Not to Invoke the Criminal Process: Low Visibility Decisions in the Administration of Justice”, Yale Law Journal, 69 (1960), pp. 543-594.

53. Gendarmerie reports, monthly and annual, from the Restoration to the Second Empire can be found in series F7 in the Archives Nationales, Paris beginning with the Ain (F7 3906-3909) and continuing alphabetically through the départements; in all, some 250 cartons.

54. See, for example, Annual Report of the Chief of the Sheffield Police and Auxiliary Services for the Year Ending 31 December 1935 (also I936-1940). 
some men managed their reports to conceal any bending of the rules to suit their own convenience. Ignace-Emile Forestier recalled an occasion early in 1902 when his company was ordered to clamp down on the number of vagabonds in their département. Patrols were ordered to saddle up at 6 a.m. and to sweep their jurisdiction until 6 p.m.; they were to take food for a brief, cold meal. After a morning of fruitless patrolling, and being extremely hungry, it occurred to brigadier Forestier that vagabonds often stopped at the outbuildings of chateaux to ask for money or food. Forestier and his subordinate therefore stopped at the house of the jardinier-concierge by the chateau of Fourgères. The concierge sat them in the window, and gave them a hot lunch, while the horses also enjoyed their oats and a rest. Just as the two gendarmes were enjoying their dessert, they saw their quarry through the window. The approaching vagabond was promptly arrested. Forestier must have reported the arrest to his superiors in a very different manner from the way in which he recounted it in his autobiography..$^{55}$ Less easy to dismiss, though perhaps as easy to explain, is the management of information which sought to cover up serious mistakes or dishonesty.

\section{RELATIONSHIPS}

In many, perhaps most work cultures, a bond is often developed between members of the workforce. In the police such bonds can be deliberately fostered to establish an esprit de corps. Small wonder then that policemen have closed ranks to defend each other from outsiders, and especially from outsiders' criticism. The camaraderie of a civilian-police section house or police station, or of a gendarmerie barracks, could lead to rough horseplay, and even to fights. The camaraderie could spill out on to the streets when men were on duty. Tricks were played on each other, sometimes to alleviate the boredom of night-time patrols, perhaps also as a way of asserting individuality and independence from the rigorous discipline, and sometimes it appears, just for the sheer fun of it. Other rules were broken, such as smoking surreptitious cigarettes while on duty, gossiping with mates, or accepting free drinks from pubs, cabarets, or vignerons, this latter being perhaps the most common, most widely ignored, and least serious of the unofficial perks accepted. Sometimes these free drinks and other perks were demanded by patrolling policemen. ${ }^{56}$ English policemen's memoirs often describe how warnings of approaching sergeants were passed to comrades so that everything would appear all correct to the supervisor's eye.

Sergeants and other superior offices could be tyrants to their subordinates,

55. Forestier, Gendarmes à la belle époque, pp. 68-69.

56. Emsley, English Police, pp. 243-244; Forestier, Gendarmes à la belle époque, p. 8I. An article by Georges Duval in L'Evènement, 28 August 1887, describes Parisian gardiens getting drinks from wine merchants. 
and some were disciplined accordingly. There were also instances of policemen turning on a superior with verbal abuse and even violence. Such interpersonal friction in barracks and police stations was as predictable as the tight camaraderie. Indeed, it is difficult to conceive of any workplace where personal animosities and power relationships do not have a role as significant as friendships and trade solidarity. Problems of police-public relations arose, however, if supervising officers deployed towards members of the population the sort of brusque officiousness which some used in dealings with their men, or if individual policemen acted in a similar way, either fired by their own importance or overzealously seeking to enforce the jurist's concept of order on a community with an alternative perception. This brings to the forefront the issue of the power relationship between police and people, and particularly the authority which the policeman can bring to bear on his fellow citizens as a result of his job. The limited historical work that has been done on this issue has emphasized the importance of cultural and political contexts for an understanding of the nature of police authority. The authority of the nineteenth-century New York "cop" was personal; it depended on his closeness to his fellow citizens. In New York and elsewhere in American cities, the cop's authority can be seen as conforming to the existing patterns of democratic government insofar as he was a product of the spoils system and a reflection of the dominant group in the urban machine. The authority of the nineteenth-century London "bobby", in contrast, was impersonal; his discipline and separation from partisan politics gave him an institutional rather than a personal aura. ${ }^{57}$ At the same time, the relatively stable politics of nineteenth-century England ensured that the bobby rarely faced confrontations with, or conducted investigations of, extremely articulate but dissatisfied social groups; and this enabled the creation and maintenance of his distinctive persona. ${ }^{58}$

The Schutzmann of Imperial Germany also appears to have had an institutional rather than a personal aura, but the plethora of petty regulations, many of which were created by police ordinances and which affected all social classes, contributed to a rather different relationship between police and people, as well as providing opportunities for satirists (see Figure 2).

It is difficult to grasp how far, and in what ways nineteenth- and early twentieth-century policemen perceived of their relationship with the public. The autobiographies and memoirs of policemen do not begin with a definition of the policeman's job; like other working-class autobiographers there is an assumption that the reader knows what the job is. Moreover, workingclass autobiographers are rarely theoreticians of their trade. John Pearman was a man of radical political ideas who contrasted the hard life of his family and "the poor Children of this Carrupt [sic] earth" with that of the 
aristocracy, and who concluded that, indeed, "there is one Law for the poor and another for the Rich". Pearman spent forty years of his long life in uniform; first, from I843 to I857 in the army and then, from I857 to I88I in the Buckinghamshire constabulary, yet his policing career hardly figures in his memoir. He recognized soldiering to be a political activity:

As my sincere impression is man was not made to Slaughter [h] is Fellow man. for any other man or state although he may have ingaged himself as an hired assassin in my mind one man [h] as as much right to the earth as another But I know we must have rulers But not as they now live in Luxury and riot. God made animated nature all ruled by a certain Law of its own But man [h] as Prostituted that Law and made artificial Laws to suit his own purpose and Aggrandizement which [h] as nothing to do with God [...]. ${ }^{59}$

Yet Pearman never pressed his analysis of the class structure and lawmaking into an assessment of his role as a policeman. Harry Daley, who served in the Metropolitan Police from I925 to 1950, may not have thought as deeply as Pearman in his autobiography, yet he expressed disgust at fascism, and had little time for politicians "with their thick skins, their cowardice, broken promises and shiftiness, [who] were not at all of the quality of my generousminded costermonger and bricklayer friends" ${ }^{60}$ Other English policemen who served during the interwar period expressed sympathy with the working class and the unemployed. The actions of policemen elsewhere also show sympathy for the poor. In December 1858 the French Minister of War ordered that gendarmes should stop personally paying the fines or organizing collections to pay the fines of poor petty offenders. ${ }^{61}$ The Italian police, both PS and Carabinieri, were not noted for their leniency or moderation in dealing with strikers, nevertheless representatives from both institutions were known to protest on behalf of strikers and to criticize landowners for creating problems in the first place by their treatment of braccianti. ${ }^{62}$ There was a recognition amongst all policeman that "on the job trouble" could involve endangering their own lives to help others; stopping runaway horses in the streets, for example, appears to have been a frequent demand on urban policemen for most of the period. And, of course, apprehending thieves was always perceived as being of benefit to all classes. ${ }^{63}$

59. Carolyn Steedman (ed.), The Radical Soldier's Tale (London, 1988), pp. 192 and 233. See also Steedman's stimulating introduction, especially, pp. 29 and 59.

6o. Harry Daley, This Small Cloud: A Personal Memoir (London, I986), p. I40.

6I. Saurel, "La Gendarmerie dans la société", 3, pp. 359-364.

62. For such comment by PS officers see, for example papers relating to trouble in Molinella during 1896-1897, Archivio di stato di Bologna, 6ab Q, I897, cart. 7/A-B Ordine pubblico dal 37 al 1362. My thanks to Steven Hughes for drawing these documents to my attention.

63. Louis Canler claimed that he determined to become a policeman when, following his departure from the army, as a bystander he had became involved in the arrest of an armed man seeking to rob an apartment in a Parisian house. Jacques Brenner (ed.), Mémoires de Canler, ancien chef du service de Sûreté (Paris, 1968) pp. 32-33. 
It is possible that some men emphasized their service role in memoirs and autobiographies so as to obscure any recognition that they were implicated in enforcing the perception of order of a dominant social class, and that they possessed the power to use violence in such enforcement. It is equally possible that many policemen, while serving, may have developed a selective recognition of the ideas underpinning the regimes by which they were employed. Individual German and Italian policemen during the interwar period, for example, worked for the Nazi and fascist states without necessarily becoming party members. Some men were purged, but most stayed on; resignation in a period of high unemployment was a courageous act, especially if a man had a wife and family, and/or could see his pension looming. Some of them may have buried themselves in hard work and the rituals of their tasks - patrolling, investigating reports from members of the public which they themselves could see at times as being malicious. ${ }^{64}$ Others probably relished the prestige and support which they now felt they received from bigger budgets, the vigorous backing from courts and government, and directives to pursue and apprehend, without legal hindrance, individuals who had commonly been seen as police property or antisocial, such as professional criminals (a category ascribed to third-time offenders), beggars, gypsies, habitual sexual offenders, and even the "work-shy" (Arbeitsscheu). The men who served in the security police and detective squads of Nazi Germany appear to have been sucked into participation in the spiralling evils of the regime because of the fusion of their organizations with the SD and because of the broad social and national culture from which they originated, rather than because they were recruited predominantly from men whose "personalities [were] highly susceptible to sanctioned violence". ${ }^{65}$

64. Robert Gellately, The Gestapo and German Society: Enforcing Racial Policy 1933-1945 (Oxford, 1990), p. 72. For some preliminary work on the police at the beginnings of fascism in Italy see Collin, "The Italian Police and Internal Security from Giolitti to Mussolini", and Dunnage, The Italian Police and the Rise of Fascism.

65. Browder, Hitler's Enforcers, p. 232 and passim for the general argument. Like a few of the "ordinary men" of Reserve Police Battalion Ior in Poland, a few policemen appear to have avoided and ignored the spirit of Nazi racial policy; and, again similarly, they do not appear to have been punished, though they could be moved to another post or department. See, for example, the activities of the Gestapo official charged with preparing the deportation lists of Jews in Bremen in 1943 described in Inge Marssolek and René Ott, Bremen im Dritten Reich. AnpassungWiderstand-Verfolgung (Bremen, 1986), pp. 34Iff. And for the "ordinary men" see Christopher J. Browning, Ordinary Men: Reserve Police Battalion IoI and the Final Solution in Poland (New York, 1992).

For police treatment of the "workshy" in Nazi Germany see Wolfgang Ayass, "Vagrants and Beggars in Hitler's Reich", in Richard J. Evans (ed.), The German Underworld: Deviants and Outcasts in German History (London, I988), p. 230. A special edition of the journal Comparativ was devoted to the policing of the Gay community in nineteenth- and twentieth-century Germany: Stephan Heiss and Wolfgang Schmale (eds), Polizei und schwule Subkulturen, Comparativ, 9 (I999), I. 


\section{SUMMATION}

All jobs have unique elements. That of the nineteenth- and early twentiethcentury policeman was physically tough, possibly much more so than many of the more conventional and better explored working-class jobs of the period. There were advantages; the pay was regular, and there was the prospect of a pension. Yet the pay and conditions were not necessarily good in comparison with those of social groups with whom the police identified, and at times this could generate precisely the same kind of industrial unrest and action as was known, and has been much better explored by historians, among other workers. Policemen also resisted internal regulations and controls like other workers, and sought to gain personal space and autonomy within the confines of their job. In these respects at least the policeman was a worker much like any other within the specificities of his tasks. But, of course, it is precisely those tasks which have probably led to the caution of many labour and social historians in recognizing, let alone exploring, the policeman as a worker. Policemen were required to enforce particular views of order; at one extreme this could mean enforcing murderous racial policies, but more often it meant maintaining the status quo and, in consequence, an unequal division of property and wealth. This set the policeman apart from the oppressed agricultural labourer, the militant coal miner or textile worker, and it could make him the physical manifestation of the oppression. But if the nineteenth- and early twentieth-century policeman was a foot soldier on the side of developing capitalism, he was also a foot soldier on the side of the dominant ideology of other societies, ${ }^{66}$ and it is this which constitutes one of the unique aspects of the job.

66. Louise I. Shelley, Policing Soviet Society: The Evolution of State Control (London, 1996), p. 27 , compares the repressive political actions of American police with that of the Soviet militia under the Bolsheviks. In both instances, she notes, unrest was brutally suppressed and people were killed. Nevertheless, she argues, in the USA "such political functions could not be sustained because the police were required to focus on the interests of the majority and uphold the institutions of representative democracy [whereas] Bolshevik leaders had no such constraint - their primary concern was to acquire and retain power". Arguments might be pressed over the police role in "the interests of the majority" and upholding the institutions of "representative democracy", yet the underlying point remains essentially valid. 